\title{
Purification and Characterization of Thermostable and Detergent-Stable $\alpha$-Amylase from Anoxybacillus sp. AH1
}

\author{
Ömer Acer ${ }^{1 *}$, Fatma Matpan Bekler ${ }^{1}$, Hemşe Pirinççioğlü, \\ Reyhan Gül Güven ${ }^{2}$ and Kemal Güven ${ }^{1}$ \\ ${ }^{1}$ Molecular Biology and Genetic Department, Faculty of Science, Dicle University, TR-21280 Diyarbakır, Turkey \\ ${ }^{2}$ Division of Science Teaching, Ziya Gökalp Faculty of Education, Dicle University, TR-21280 Diyarbakır, Turkey \\ Received: February 12, 2015 \\ Accepted: September 11, 2015
}

\begin{abstract}
Summary
A thermostable and detergent-stable $\alpha$-amylase from a newly isolated Anoxybacillus sp. AH1 was purified and characterized. Maximum enzyme production $(1874.8 \mathrm{U} / \mathrm{mL})$ was obtained at $24 \mathrm{~h}$ of incubation. The amylase was purified by using Sephadex G-75 gel filtration, after which an 18-fold increase in specific activity and a yield of $9 \%$ were achieved. The molecular mass of the purified enzyme was estimated at $85 \mathrm{kDa}$ by sodium dodecyl sulphate-polyacrylamide gel electrophoresis (SDS-PAGE). The optimum $\mathrm{pH}$ and temperature values of the enzyme were 7.0 and $60^{\circ} \mathrm{C}$, respectively. The enzyme was highly stable in the presence of $30 \%$ glycerol, retaining $85 \%$ of its original activity at $60{ }^{\circ} \mathrm{C}$ within 120 $\min . K_{\mathrm{m}}$ and $v_{\max }$ values were $0.102 \mu \mathrm{mol}$ and $0.929 \mu \mathrm{mol} / \mathrm{min}$, respectively, using Lineweaver-Burk plot. The enzyme activity was increased by various detergents, but it was significantly inhibited in the presence of urea. $\mathrm{Mg}^{2+}$ and $\mathrm{Ca}^{2+}$ also significantly activated $\alpha$-amylase, while $\mathrm{Zn}^{2+}, \mathrm{Cu}^{2+}$ and metal ion chelators ethylenediaminetetraacetic acid (EDTA) and 1,10-phenanthroline (phen) greatly inhibited the enzyme activity. $\alpha$-Amylase activity was enhanced by $\beta$-mercaptoethanol ( $\beta$-ME) and dithiothreitol (DTT) to a great extent, but inhibited by $p$-chloromercuribenzoic acid (PCMB). Iodoacetamide (IAA) and $\mathrm{N}$-ethylmaleimide (NEM) had a slight, whereas phenylmethylsulfonyl fluoride (PMSF) had a strong inhibitory effect on the amylase activity.
\end{abstract}

Key words: detergent-stable $\alpha$-amylase, Anoxybacillus sp. AH1, enzyme activity inhibition, enzyme purification

\section{Introduction}

Alpha-amylases ( $\alpha$-1,4-glucan-4-glucanohydrolase; EC 3.2.1.1) are a family of endoamylases that randomly cleave $\alpha$-1,4-glucosidic linkages in starch and related carbohydrates to produce oligosaccharides of different lengths and glucose in the $\alpha$-anomeric form (1-3). $\alpha$-Amylases can be obtained from different sources, including plants, animals and microorganisms $(4,5)$. Microbial enzymes are generally preferred in several industrial applications due to advantages such as wide use, efficient production, stability and cost-effectiveness $(3,6)$. Amylases are one of the most important families of enzymes used in starch pro- cessing, brewing and sugar production $(7,8)$, desizing in textile industries, in detergent manufacturing processes, drugs and pharmaceuticals (2), in filling of pores of paper, in removing food and starch stains in dry cleaning (9), and production of corn and chocolate syrup (10).

Amylases have been obtained from thermophilic bacteria for several years. In recent studies, amylases have been studied from thermophilic Bacillus species such as Bacillus subtilis $(8,11)$, Bacillus licheniformis $(7,12,13)$, Bacillus amyloliquifaciens (14), Bacillus cereus (2), Bacillus thermooleovorans (15), Anoxybacillus flavithermus (16), Anoxybacillus amylolyticus (17), Anoxybacillus sp. $(3,9,18)$, Geobacillus 
stearothermophilus (19), Geobacillus thermooleovorans (20) and Geobacillus sp. $(21,22)$.

There are a few studies regarding purification and characterization of $\alpha$-amylases in Anoxybacillus species. The purpose of this study is to purify and characterize a biotechnologically important $\alpha$-amylase, rather stable in several detergent formulations, produced by thermophilic Anoxybacillus sp. AH1 isolated from Dargeçit hot spring in Turkey.

\section{Materials and Methods}

\section{Materials}

Sephadex G-75, 3,5-dinitrosalicylic acid (DNS), bovine serum albumin (BSA), 1,10-phenanthroline (phen), dithiothreitol (DTT), $p$-chlorobenzoic acid (PCMB), N-ethylmaleimide (NEM), iodoacetamide (IAA), phenylmethanesulfonyl fluoride (PMSF), sodium dodecyl sulphate (SDS), Tween 40, Triton X-100 and $\alpha$-amylase (Type II-A $\geq 1500 \mathrm{U} /$ mg from Bacillus sp.) were purchased from Sigma (Sigma-Aldrich, St Louis, MO, USA). Ethylenediaminetetraacetic acid (EDTA) and $\beta$-mercaptoethanol $(\beta-\mathrm{ME})$ and all culture media (nutrient broth) were provided by Merck (Darmstadt, Germany). All chemicals were of analytical grade.

\section{Bacterial strain and medium}

The strain AH1 used in this study was isolated from Dargeçit hot spring in Turkey and then identifed and characterized by morphological, physiological and biochemical tests and 16S rRNA sequence analysis by Acer et al. (23). A volume of $1 \mathrm{~mL}$ of culture was inoculated in a 100-mL Erlenmeyer flask containing $25 \mathrm{~mL}$ of nutrient broth composed of (in $\mathrm{g} / \mathrm{L}$ ): beef extract 10 , peptone 10 and $\mathrm{NaCl} 5$, and incubated overnight at $60^{\circ} \mathrm{C}$ for $24 \mathrm{~h}$ in a shaker. Growth was followed by absorbance measurements at $540 \mathrm{~nm}$. The culture was centrifuged at $8200 \times g$ and $4{ }^{\circ} \mathrm{C}$ for $10 \mathrm{~min}$ and the cell-free supernatant was used for the estimation of amylolytic enzyme activity.

Genomic DNA extraction, PCR-mediated amplification of the $16 \mathrm{~S}$ rDNA and purification of the PCR products were performed as described previously $(24,25)$. The 1134 nucleotides of the 16S rRNA gene were specified (23). A BLAST search (26) was used in order to compare these sequences with other Anoxybacillus species that produce amylolytic enzymes. The $16 \mathrm{~S}$ rRNA gene sequences of the species most closely related to our strain were retrieved from the database. The CLC Sequence Viewer v. 6.0 software package (27) was used for the construction of phylogenetic tree.

\section{Enzyme activity assay}

The enzyme activity was determined according to Bernfeld (28): $50 \mu \mathrm{L}$ of enzyme solution were added into $200 \mu \mathrm{L}$ of soluble starch (Merck) $(0.5 \%$, by mass per volume) in $0.1 \mathrm{M}$ Tris- $\mathrm{HCl}$ buffer, $\mathrm{pH}=7.0$, at $60^{\circ} \mathrm{C}$ for $30 \mathrm{~min}$. The reaction was stopped by the addition of $0.4 \mathrm{~mL}$ of 3,5-dinitrosalicylic acid (DNS) reagent and the mixture was boiled for $5 \mathrm{~min}$. After cooling to room temperature, the mixture was diluted with $3.0 \mathrm{~mL}$ of distilled water and the absorption was then measured at $489 \mathrm{~nm}$. One unit of amylase activity was defined as the amount of enzyme that released $1 \mu \mathrm{mol}$ of maltose per minute per $\mathrm{mL}$ under the assay conditions. The protein content in the extracellular extracts was determined by the method of Lowry et al. (29) using bovine serum albumin (BSA) as a standard in this procedure.

\section{Effect of incubation time on bacterial growth and $\alpha$-amylase production}

In order to determine the effect of incubation time on bacterial growth and $\alpha$-amylase production, $1 \mathrm{~mL}$ of the isolate was inoculated into $100 \mathrm{~mL}$ of nutrient broth and the samples were taken every 3 hours over a 72-hour period. The growth was determined by measuring the increase in absorbance at $540 \mathrm{~nm}$. After centrifugation, the supernatant was used for measuring the enzyme activity.

\section{Purification of $\alpha$-amylase}

The strain AH1 was grown in nutrient broth for $24 \mathrm{~h}$ and was removed by centrifugation at $8200 \times g$ and $4{ }^{\circ} \mathrm{C}$ for $10 \mathrm{~min}$. The supernatant was precipitated using ammonium sulphate to $80 \%$ saturation. The precipitate was then dissolved in $0.1 \mathrm{M}$ Tris- $\mathrm{HCl}$ buffer $(\mathrm{pH}=7.0)$, and dialyzed overnight against the same buffer. Gel filtration of the precipitate was done on a Sephadex G-75 column $(1.5 \mathrm{~cm}$ $\times 30 \mathrm{~cm}$ ), pre-equilibrated with $0.1 \mathrm{M}$ Tris- $\mathrm{HCl}, \mathrm{pH}=7.0$. An elution was performed with the same buffer at a flow rate of $3 \mathrm{~mL} / \mathrm{min}$. The enzyme containing fractions was collected and concentrated by ultrafiltration. Protein content and enzyme activity were determined after each step. All purification procedures were carried out at $4{ }^{\circ} \mathrm{C}$.

\section{Determination of purified $\alpha$-amylase molecular mass and activity}

\section{SDS-PAGE}

Sodium dodecyl sulphate-polyacrylamide gel electrophoresis (SDS-PAGE) was carried out for the determination of purity and molecular mass of the amylase as described by Laemmli (30). Samples were heated at 100 ${ }^{\circ} \mathrm{C}$ for $5 \mathrm{~min}$ before electrophoresis. Gels were stained with Coomassie Brilliant Blue R250. The molecular mass of the enzyme was estimated using molecular mass markers (catalog number SDS7B2, Sigma): $\alpha$-2-macroglobulin (180 kDa), $\beta$-galactosidase (116 kDa), lactoferrin (90 kDa), pyruvate kinase $(58 \mathrm{kDa})$, fumarase $(48.5 \mathrm{kDa})$, lactic dehydrogenase $(36.5 \mathrm{kDa})$ and triosephosphate isomerase (26.6 kDa). For zymography of amylase activity, the native gel containing $0.2 \%$ soluble starch was used. The gels were stained with iodine solution after electrophoresis. Clear bands indicated the presence of amylase activity. The enzyme activity band was compared with commercial $\alpha$-amylase band (58 kDa) from Bacillus sp.

\section{Effect of $p H$ and temperature, and kinetic properties of purified enzyme}

The effect of $\mathrm{pH}$ on amylase activity was determined at $60{ }^{\circ} \mathrm{C}$ for $30 \mathrm{~min}$ in different buffers $(0.1 \mathrm{M}$ citric acid 
buffer, $\mathrm{pH}=4.0-5.5$; sodium phosphate buffer, $\mathrm{pH}=6.0-6.5$; Tris- $\mathrm{HCl}$ buffer, $\mathrm{pH}=7.0-9.0$; and glycine- $\mathrm{NaOH}$ buffer, $\mathrm{pH}=9.5-11.0)$. The effect of temperature on amylase activity was determined by assaying the enzyme activity in the range from 30 to $90^{\circ} \mathrm{C}$ for $30 \mathrm{~min}$.

In order to test the thermostability of the purified enzyme, the residual enzyme activity was measured after incubating an aliquot of the enzyme at $60^{\circ} \mathrm{C}$ for $20,40,60$, 80 and $120 \mathrm{~min}$. The enzyme was also incubated with 30 $\%$ glycerol. Aliquots were withdrawn at desired time intervals and the remaining activity was measured under enzyme assay conditions. The non-heated enzyme was considered as control (100\%).

Soluble starch was used for determination of Michaelis constant $\left(K_{\mathrm{m}}\right)$ and the rate of reaction $\left(v_{\max }\right)$. The enzyme was assayed at various soluble starch mass per volume ratios ranging from 0.5 to $3 \%$ in Tris- $\mathrm{HCl}$ buffer. All reactions were carried out at $60{ }^{\circ} \mathrm{C}$ and $\mathrm{pH}=7.0$ for $30 \mathrm{~min}$. $K_{\mathrm{m}}$ and $v_{\max }$ values were estimated from the Lineweaver-Burk plot.

\section{Effect of different metal ions and chemical reagents}

To study the effect of different metal ions $\left(\mathrm{Cu}^{2+}, \mathrm{Zn}^{2+}\right.$, $\mathrm{Ca}^{2+}$ and $\left.\mathrm{Mg}^{2+}\right)$, chelating agents (EDTA and phen), some chemicals (DTT, $\beta$-ME, PCMB, PMSF, NEM and IAA), various surfactants (SDS, Tween 40, Triton X-100 and commercial detergent) and urea on amylase activity, the purified enzyme was preincubated with all agents for $15 \mathrm{~min}$. The remaining activity was calculated using the enzyme assay under standard assay conditions. Activity in the absence of any additives (control) was taken as $100 \%$. All of the used metals were in the chloride form. Divalent metals, chelating agents, chemicals, surfactants and urea were dissolved in $0.1 \mathrm{M}$ Tris- $\mathrm{HCl}$ buffer $(\mathrm{pH}=7.0)$, whereas PMSF and NEM were dissolved in ethanol, and phen in methanol.

\section{Results and Discussion}

The comparison of 16S rRNA sequence of the strain AH1 with those of the amylase-producing Anoxybacillus species showed high similarity with A. flavithermus (Fig. 1). The strain AH1 was identified and named Anoxybacillus sp. AH1 [DSMZ (Deutsche Sammlung von Mikroorganismen und Zellkulturen) Deposit Number: 23210, GenBank Accession Number: KP172526] (23).

\section{$\alpha$-Amylase production and purification}

The time-dependent amylase production was maximum (1874 U/mL) at $24 \mathrm{~h}$ (Fig. 2). There are several studies on thermophilic Anoxybacillus species that possess the ability to produce amylases $(3,9,16,18,31)$. The steps used for the $\alpha$-amylase extraction from Anoxybacillus sp. AH1 and purification are shown in Table 1 . It can be seen clearly that $\alpha$-amylase was purified up to 18 -fold with a yield of $9 \%$ of the pure enzyme.

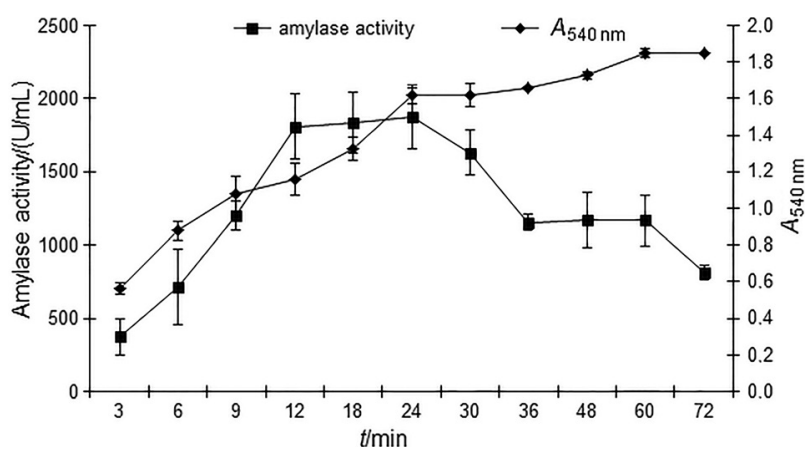

Fig. 2. Time course of bacterial growth and Anoxybacillus sp. AH1 amylase production. The cells were incubated at $\mathrm{pH}=7.0$ and $60{ }^{\circ} \mathrm{C}$ for $72 \mathrm{~h}$. The results represent the mean values of three experiments, and bars indicate standard deviation. Absence of bars indicates that errors were smaller than symbols

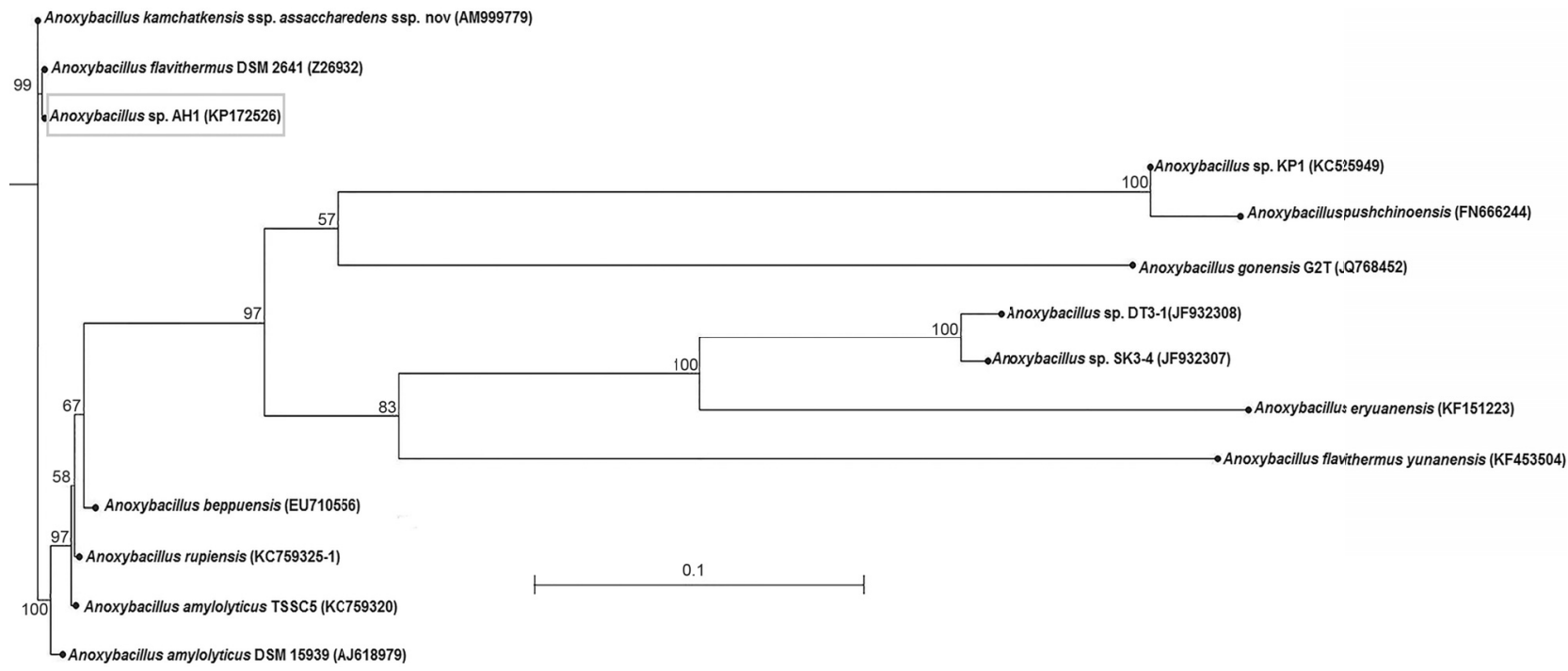

Fig. 1. 16S rDNA sequence-based phylogenetic neighbour-joining tree showing the phylogenetic relationship of AH1 strain relative to other amylase-producing strains of the genus Anoxybacillus. The tree topology was obtained by calculation using the CLC Sequence Viewer v. 6 program (27). Bootstrap values (\%) from 1000 replicates are shown. Bar indicates 0.1 nucleotide substitutions per position 
Table 1. Purification steps of $\alpha$-amylase

\begin{tabular}{|c|c|c|c|c|c|}
\hline \multirow{2}{*}{ Purification step } & $m$ (total protein) & Total activity & Specific activity & Purification & Yield \\
\hline & $\mathrm{mg}$ & $\mathrm{U}$ & $\mathrm{U} / \mathrm{mg}$ & (fold) & $\%$ \\
\hline Crude extract & 11.2 & 17024 & 1520 & 1 & 100 \\
\hline Ammonium sulphate and precipitation/dialysis & 0.268 & 4559.21 & 17012 & 11 & 27 \\
\hline Sephadex G-75 & 0.055 & 1488.57 & 27065 & 18 & 9 \\
\hline
\end{tabular}

SDS-PAGE showed that the molecular mass of the $\alpha$-amylase from Anoxybacillus sp. AH1 determined by Commassie staining was around $85 \mathrm{kDa}$ (Fig. 3). Non-denaturing PAGE and zymogram analyses also show the presence of $\alpha$-amylase activity. The molecular masses of the $\alpha$-amylases from various bacilli were reported to be 43, 50, 60.5-86, 91 and 97 kDa from Anoxybacillus beppuensis TSSC-1 (18), Anoxybacillus sp. SK3-4 (32), Bacillus sp. A3-15 (4), Bacillus sp. AAH-31 (33) and Geobacillus sp. IIPTN (21), respectively.

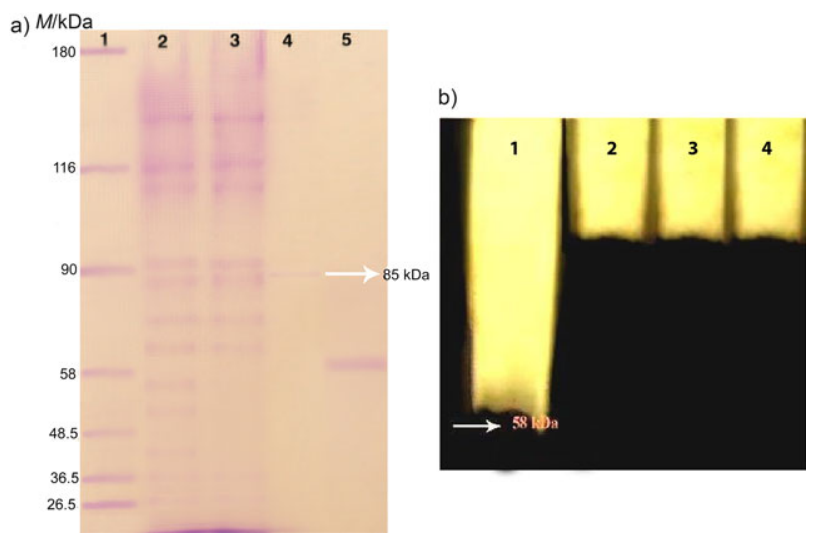

Fig. 3. Amylase activity determined by: a) SDS-PAGE staining with Coomassie Brilliant Blue R250: lane 1=molecular mass markers [catalog number SDS7B2, Sigma: $\alpha$-2-macroglobulin $(180 \mathrm{kDa}), \beta$-galactosidase (116 kDa), lactoferrin $(90 \mathrm{kDa})$, pyruvate kinase $(58 \mathrm{kDa})$, fumarase $(48.5 \mathrm{kDa})$, lactic dehydrogenase $(36.5 \mathrm{kDa})$, triosephosphate isomerase $(26.5 \mathrm{kDa})]$, lanes $2,3,4$ and $5=$ staining of crude extract and purified amylase (ammonium sulphate precipitation/dialysis and Sephadex G-75), respectively; and b) zymogram: lane $1=$ commercial $\alpha$-amylase (58 $\mathrm{kDa}$ ); lanes 2, 3 and $4=$ =iodine solution staining of crude extract and purified amylase (ammonium sulphate precipitation/dialysis and Sephadex G-75 column), respectively

\section{Influence of $p H$, thermal and kinetic properties of purified enzyme}

As it can be seen in Fig. 4, the purified enzyme exhibited maximum activity at $\mathrm{pH}=7.0$, and retained amylase activity of 80,88 and $83 \%$ at $\mathrm{pH}=6.5,7.5$ and 8.0 , respectively. Similar optimum $\mathrm{pH}$ value has been reported for $\alpha$-amylase from Anoxybacillus sp. KP1 (9), A. beppuensis TSSC-1 (18), Bacillus stearothermophilus (34), Bacillus sp. 1-3 (35) and Anoxybacillus gonensis A4 (36).

The thermostable starch-digesting amylases are rather important in the process of starch hydrolysis because the industrial aplications involving $\alpha$-amylases operate at high temperatures exceeding $50{ }^{\circ} \mathrm{C}$, due to higher reac-

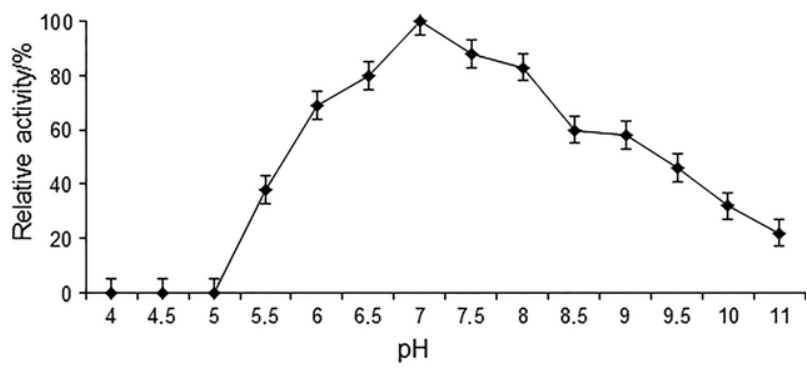

Fig. 4. Effect of $\mathrm{pH}$ on the activity of Anoxybacillus sp. AH1 amylase. The values are shown as percentages of the maximum enzyme activity observed at $\mathrm{pH}=7.0$ and $60{ }^{\circ} \mathrm{C}$, which is taken as $100 \%$

tion rates at these temperatures (35). The purified amylolytic activity was assayed at different temperatures exhibiting maximum activity at $60{ }^{\circ} \mathrm{C}$, and displayed 92 and 99 $\%$ of its peak activity at 50 and $55{ }^{\circ} \mathrm{C}$, respectively (Fig. $5 a)$. In recent studies, the optimum temperature of $60^{\circ} \mathrm{C}$ has been reported for a few $\alpha$-amylases from Anoxybacillus species $(3,9,32)$. As shown in Fig. $5 \mathrm{~b}$, the enzyme was highly stable up to $1 \mathrm{~h}$ and retained $93 \%$ of the original activity at $60{ }^{\circ} \mathrm{C}$. However, the enzyme activity decreased
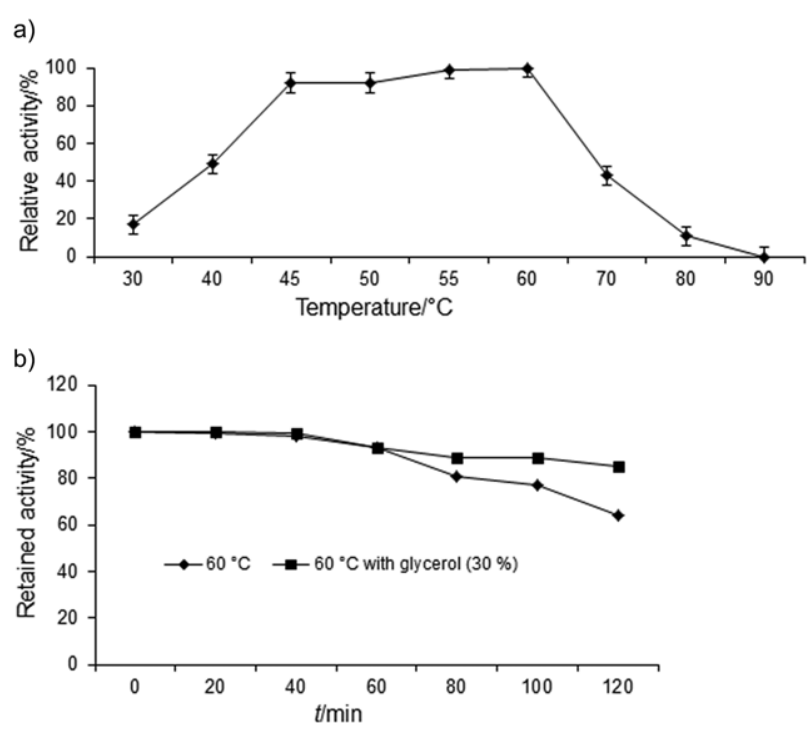

Fig. 5. Effect of: a) temperature on the activity of Anoxybacillus sp. AH1 amylase. The values are shown as percentages of the maximum enzyme activity observed at $60^{\circ} \mathrm{C}$, which is taken as $100 \%$, and b) effect of temperature on the stability of Anoxybacillus sp. AH1 amylase. The $\alpha$-amylase was incubated at $60^{\circ} \mathrm{C}$ for different time periods (20-120 min). The stability of unheated crude enzyme was taken as $100 \%$. The remaining amylolytic activity was measured under standard assay conditions 
after $1 \mathrm{~h}$, after which $30 \%$ glycerol was found to help the enzyme stability at $60{ }^{\circ} \mathrm{C}$ up to $2 \mathrm{~h}$ by retaining $85 \%$ of the original activity. The stabilizing effect of glycerol on thermostability of the enzyme has also been reported in previous studies $(37,38)$. The results show that this thermostable enzyme could be a good candidate for the efficient and quick hydrolysis of starches.

As shown in Fig. 6, kinetic studies of the enzyme were carried out using various concentrations of soluble starch as substrate under standard assay conditions. Using the Lineweaver-Burk plot, the $K_{\mathrm{m}}$ and $v_{\max }$ values of $0.102 \mu \mathrm{mol}$ and $0.929 \mu \mathrm{mol} / \mathrm{min}$ were obtained, respectively.

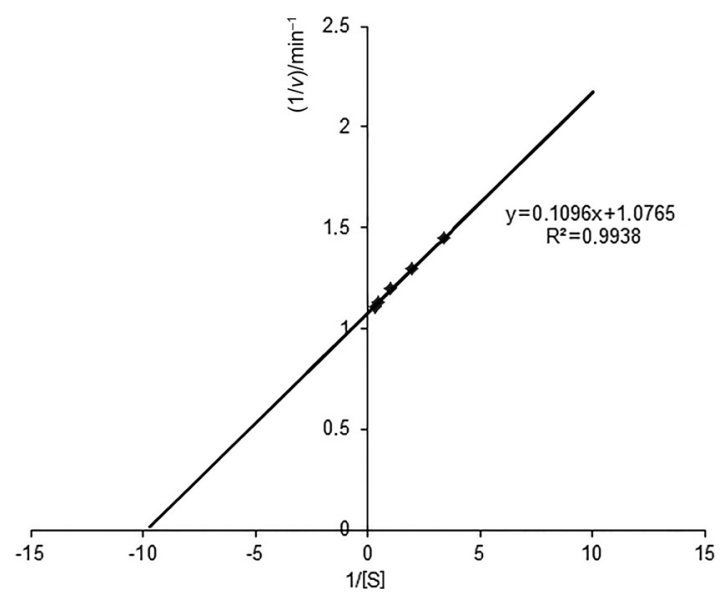

Fig. 6. Lineweaver-Burk plot for $K_{\mathrm{m}}$ and $v_{\max }$ values of the amylase in the presence of different concentrations of soluble starch [S]

\section{Influence of different metal ions and chemical reagents}

As shown in Table 2, $\alpha$-amylase was significantly activated by $\mathrm{Mg}^{2+}(41 \%$ at $8 \mathrm{mM})$ and $\mathrm{Ca}^{2+}(70 \%$ at $8 \mathrm{mM})$. Calcium ion is well known to activate most amylases to a great extent. Arikan (4) and Srivastava (39) reported that $\alpha$-amylase activity was enhanced by $\mathrm{Ca}^{2+}$. In addition, Rao and Satyanaryana (40) also found that the amylase activity was increased in the presence of $\mathrm{Mg}^{2+}$. Stability of an enzyme in the presence of metal salts plays a crucial role in their industrial application. It is already known that most enzymes require the presence of metal ion activators to express their full catalytic activity $(41,42)$.

In the present study, enzyme activity was greatly inhibited by $\mathrm{Zn}^{2+}(93 \%$ at $1 \mathrm{mM})$ and $\mathrm{Cu}^{2+}(76 \%$ at $0.5 \mathrm{mM}$ and $100 \%$ at $1 \mathrm{mM}$ ) as well as by the metal ion chelators EDTA $(63 \%$ at $10 \mathrm{mM})$ and phen $(22 \%$ at $10 \mathrm{mM})$. It is known that $\mathrm{Cu}^{2+}(43,44), \mathrm{Zn}^{2+}$ and phen (45) have inhibitory effects on $\alpha$-amylase. EDTA generally shows noncompetitive inhibition of amylase activity and a slight inhibition in the present study may indicate that it is a metalloenzyme $(4,46,47)$.

$\beta$-ME and DTT containing SH groups were found to enhance $\alpha$-amylase activity for 64 and $106 \%$, respectively, at $10 \mathrm{mM}$. However, the enzymatic activity was inhibited by PCMB (52\% at $4 \mathrm{mM})$. This result shows the presence of at least one essential cysteine residue in the active site of the enzyme, modified by the chemicals. Previous studies showed that the amylase activity increased in the presence of $\beta$-ME $(41,43)$ and DTT $(43)$. Srivastava (39) found a similar inhibition effect by PCMB. IAA and NEM had little effect on the enzyme activity. This phenomenon further supported the existence of cysteine on the active sites of purified amylase. Hsieh et al. (48) also determined that IAA and NEM partially inhibited amylase activity. PMSF inhibited the enzyme strongly (60\% at $4 \mathrm{mM}$ ) (Table 2). The inhibition of $\alpha$-amylase from Anoxybacillus sp. AH1 by PMSF suggested the importance of the seryl hydroxyl group in enzyme catalysis. Arikan (4), Rao and Satyanaryana (40), Shafiei et al. (44) and Tatar (45) also reported that the activity of $\alpha$-amylase was inhibited by PMSF.

Table 2. Effect of divalent metal ions, metal ion chelators and chemicals on the activity of purified Anoxybacillus sp. AH1 $\alpha$-amylase

\begin{tabular}{|c|c|c|c|c|c|c|c|c|}
\hline \multirow{3}{*}{$\begin{array}{l}\text { Divalent metals, } \\
\text { ion chelators } \\
\text { and chemicals }\end{array}$} & \multicolumn{8}{|c|}{$c / \mathrm{mM}$} \\
\hline & 0.05 & 0.1 & 0.5 & 1 & 2 & 4 & 8 & 10 \\
\hline & \multicolumn{8}{|c|}{ Retained amylase activity /\% } \\
\hline $\mathrm{Ca}^{2+}$ & - & - & - & 146 & 152 & 159 & 170 & - \\
\hline $\mathrm{Mg}^{2+}$ & - & - & - & 109 & 121 & 133 & 141 & - \\
\hline $\mathrm{Cu}^{2+}$ & 65 & 62 & 24 & 0 & - & - & - & - \\
\hline $\mathrm{Zn}^{2+}$ & 74 & 32 & 15 & 7 & 0 & - & - & - \\
\hline EDTA & - & - & - & 88 & 58 & 57 & 53 & 37 \\
\hline phen & - & - & & 99 & 97 & 87 & - & 78 \\
\hline DTT & - & - & - & 102 & 118 & 124 & - & 206 \\
\hline$\beta-\mathrm{ME}$ & - & - & - & 120 & 121 & 144 & - & 164 \\
\hline PMSF & - & - & - & 51 & 50 & 40 & - & 37 \\
\hline NEM & - & - & - & 89 & ND & ND & $\mathrm{ND}$ & ND \\
\hline IAA & - & - & - & 81 & ND & ND & ND & ND \\
\hline urea & - & 84 & 56 & 37 & 9 & - & - & - \\
\hline
\end{tabular}

-=not tested, ND=not determined. Phen=1,10-phenanthroline, DTT=dithiothreitol, $\beta$-ME= $\beta$-mercaptoethanol,

PMSF=phenyilmethylsulfonyl fluoride, $\mathrm{PCMB}=p$-chloromercuribenzoic acid, $\mathrm{NEM}=N$-methylmaleimide, IAA=iodoacetamide 
As it can be seen in Table 2, the enzyme activity was significantly inhibited by urea $(91 \%$ at $2 \mathrm{mM})$, which was also confirmed by other authors $(4,41,46)$. The reason for this inhibition is that urea denatures the enzyme (41).

The use of $\alpha$-amylases in detergent formulations is known to present problems because it depends on their activity and stability. The enzymes thus need to be stable against detergents (49). As it can be seen in Fig. 7, $\alpha$-amylase activity was increased with the addition of $0.5 \%$ of

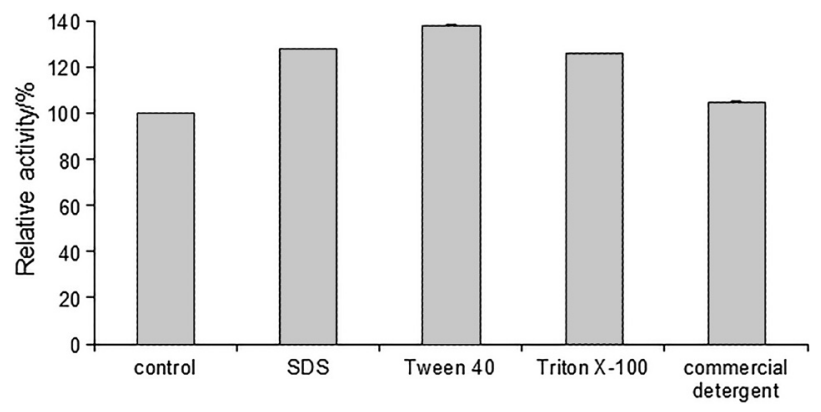

Fig. 7. Effect of surfactants and some commercial detergents on the amylolytic activity. The results represent the mean value of three experiments. Absence of bars indicates that errors were smaller than symbols

several detergents, SDS (28\%), Tween 40 (38\%), Triton X-100 (26\%) and commercial detergent (5\%). The increase of enzyme activity is possibly due to the effect of the surfactant on the folding of substrate moiety as well as an increase in the hydrophobic interactions, which play a crucial role in the stability of the protein tertiary structure and direct interaction with the protein molecule (41). Shafiei et al. (44), Tatar (45) and Negi and Banerjee (41) reported that $\alpha$-amylase showed remarkable stability towards $0.5 \%$ SDS and $2 \%$ Triton X-100, Tween 80 and Tween 20. In this study, the thermostable $\alpha$-amylase was found to be stable against detergents and the $\alpha$-amylase activity was increased by several detergents compared with other studies, so it may be used as an ingredient in detergent formulations for automatic dishwashers and laundries.

\section{Conclusion}

The present study shows that $\alpha$-amylase from a newly isolated Anoxybacillus sp. AH1 is thermostable and detergent stable. The activity of the enzyme was also increased by metal ions such as calcium and magnesium. It is well known that stability of an enzyme in the presence of metal salts and in detergents plays a crucial role in their industrial application. The effect of various inhibitors and chemicals on the amylase activity was also evaluated in the study, which may further clarify the nature of the purified enzyme.

\section{Acknowledgements}

The paper was supported by the Scientific Research Commission of Dicle University, Diyarbakir, Turkey (Projects DUAPK-09-FF-51).

\section{References}

1. Nazmi AR, Reinisch T, Hinz HJ. Ca-binding to Bacillus licheniformis $\alpha$-amylase (BLA). Arch Biochem Biophys. 2006; 45:18-25.

http://dx.doi.org/10.1016/j.abb.2006.04.004

2. Annamalai N, Thavasi R, Vijayalakshmi S, Balasubramanian T. Extraction, purification and characterization of thermostable, alkaline tolerant $\alpha$-amylase from Bacillus cereus. Indian J Microbiol. 2011;51:424-9.

http://dx.doi.org/10.1007/s12088-011-0160-z

3. Chai YY, Rahman RNZRA, Illias RM, Goh KM. Cloning and characterization of two new thermostable and alkalitolerant $\alpha$-amylases from the Anoxybacillus species that produce high levels of maltose. J Ind Microbiol Biotechnol. 2012;39: 731-41. http://dx.doi.org/10.1007/s10295-011-1074-9

4. Arikan B. Highly thermostable, thermophilic, alkaline, SDS and chelator resistant amylase from a thermophilic Bacillus sp. isolate A3-15. Bioresour Technol. 2008;99:3071-6. http://dx.doi.org/10.1016/j.biortech.2007.06.019

5. Pandey A, Nigam P, Soccol CR, Soccol VT, Sing D, Mohan R. Advences in microbial amylases. Biotechnol Appl Biochem. 2000;31:135-52. http://dx.doi.org/10.1042/BA19990073

6. Kunamneni A, Permaul K, Singh S. Amylase production in solid state fermantation by the thermophilic fungus Thermomyces lanuginosus. J Biosci Bioeng. 2005;100:168-71. http://dx.doi.org/10.1263/jbb.100.168

7. Abdel-Fattah YR, Soliman NA, El-Toukhy NM, El-Gendi H, Ahmed RS. Production, purification, and characterization of thermostable $\alpha$-amylase produced by Bacillus licheniformis isolate AI20. J Chem. 2013;2013:Article ID 673173. http://dx.doi.org/10.1155/2013/673173

8. Asgher M, Asad MJ, Rahman SU, Legge RL. A thermostable $\alpha$-amylase from a moderately thermophilic Bacillus subtilis strain for starch processing. J Food Eng. 2007;79:950-5. http://dx.doi.org/10.1016/j.jfoodeng.2005.12.053

9. Matpan Bekler F, Güven K. Isolation and production of thermostable $\alpha$-amylase from thermophilic Anoxybacillus sp. KP1 from Diyadin hot spring in Ağri, Turkey. Biologia 2014; 69:419-27. http://dx.doi.org/10.2478/s11756-014-0343-2

10. Gupta R, Gigras P, Mohapatra H, Goswami VK, Chauhan B. Microbial $\alpha$-amylases: a biotechnological perspective. Process Biochem. 2003;38:1599-616. http://dx.doi.org/10.1016/S0032-9592(03)00053-0

11. Demirkan E. Production, purification, and characterization of $\alpha$-amylase by Bacillus subtilis and its mutant derivates. Turk J Biol. 2011;35:705-12. http://dx.doi.org/10.3906/biy-1009-113

12. Božić N, Ruiz J, López-Santín J, Vujčić Z. Production and properties of the highly efficient raw starch digesting $\alpha$-amylase from a Bacillus licheniformis ATCC 9945a. Biochem Eng J. 2011;53:203-9. http://dx.doi.org/10.1016/j.bej.2010.10.014

13. Hmidet N, Bayoudh A, Berrin JG, Kanoun S, Juge N, Nasri M. Purification and biochemical characterization of a novel $\alpha$-amylase from Bacillus licheniformis NH1: cloning, nucleotide sequence and expression of amyN gene in Escherichia coli. Process Biochem. 2008;43:499-510. http://dx.doi.org/10.1016/j.procbio.2008.01.017

14. Kikani BA, Singh SP. Single step purification and characterization of a thermostable and calcium independent $\alpha$-amylase from Bacillus amyloliquifaciens TSWK1-1 isolated from Tulsi Shyam hot spring reservoir, Gujarat (India). Int J Biol Macromol. 2011;48:676-81.

http://dx.doi.org/10.1016/j.ijbiomac.2011.02.010 
15. Malhotra R, Noorwez SM, Satyanarayana T. Production and partial characterization of thermostable and calcium-independent $\alpha$-amylase of an extreme thermophile Bacillus thermooleovorans NP54. Lett Appl Microbiol. 2000;31:378-84. http://dx.doi.org/10.1046/j.1472-765x.2000.00830.x

16. Tawil G, Viksø-Nielsen A, Rolland-Sabaté A, Colonna P, Buléon A. Hydrolysis of concentrated raw starch: a new very efficient $\alpha$-amylase from Anoxybacillus flavothermus. Carbohydr Polym. 2012;87:46-52.

http://dx.doi.org/10.1016/j.carbpol.2011.07.005

17. Poli A, Salerno A, Laezza G, di Donato P, Dumontet S, Nicolaus B. Heavy metal resistance of some thermophiles: potential use of $\alpha$-amylase from Anoxybacillus amylolyticus as a microbial enzymatic bioassay. Res Microbiol. 2009;160:99106. http://dx.doi.org/10.1016/j.resmic.2008.10.012

18. Kikani BA, Singh SP. The stability and thermodynamic parameters of a very thermostable and calcium-independent $\alpha$ -amylase from a newly isolated bacterium, Anoxybacillus beppuensis TSSC-1. Process Biochem. 2012;47:1791-8. http://dx.doi.org/10.1016/j.procbio.2012.06.005

19. Al-Qodah Z. Production and characterization of thermostable $\alpha$-amylase by thermophilic Geobacillus stearothermophilus. Biotechnol J. 2006;1:1850-7. http://dx.doi.org/10.1002/biot.200600033

20. Mehta D, Satyanarayana T. Biochemical and molecular characterization of recombinant acidic and thermostable rawstarch hydrolysing $\alpha$-amylase from an extreme thermophile Geobacillus thermoleovorans. J Mol Catal B: Enzym. 2013; 85-86:229-38.

http://dx.doi.org/10.1016/j.molcatb.2012.08.017

21. Dheeran P, Kumar S, Jaiswal YK, Adhikari DK. Characterization of hyperthermostable $\alpha$-amylase from Geobacillus sp. IIPTN. Appl Microbiol Biotechnol. 2010;86:1857-66. http://dx.doi.org/10.1007/s00253-009-2430-9

22. Mollania N, Khajeh K, Hosseinkhani S, Dabirmanesh B. Purification and characterization of a thermostable phytate resistant $\alpha$-amylase from Geobacillus sp. LH8. Int J Biol Macromol. 2010;46:27-36.

http://dx.doi.org/10.1016/j.ijbiomac.2009.10.010

23. Acer Ö, Pirinççioğlu H, Matpan Bekler F, Gül Güven R, Güven K. Anoxybacillus sp. AH1, an $\alpha$-amylase producing thermophilic bacterium isolated from Dargeçit hot spring. Biologia. 2015;70:853-62. http://dx.doi.org/10.1515/biolog-2015-0111

24. Rainey FA, Fritze D, Stackebrandt E. The phylogenetic diversty of thermophilic members of the genus Bacillus as revealed by 16S rDNA analysis. FEMS Microbiol Lett. 1994;115: 205-12. http://dx.doi.org/10.1016/0378-1097(94)90015-9

25. Rainey FA, Ward-Rainey N, Kroppenstedt RM, Stackebrandt E. The genus Nocardiopsis represents a phylogenetically coherent taxon and a distinct Actinomycete lineage: proposal of Nocardiomaceae fam. nov. Int J Syst Bacteriol. 1996;46: 1088-92. http://dx.doi.org/10.1099/00207713-46-4-1088

26. GenBank ${ }^{\circledast}$. Bethesda, MD, USA: National Center for Biotechnology Information (NCBI); 2015. Available from: http:// www.ncbi.nlm.nih.gov/.

27. CLC sequence viewer. Aarhus, Denmark: CLC bio, a QIAGEN Company; 2015. Available from: http://www.clcbio. com/products/clcsequence-viewer/.

28. Bernfeld P. Amylases, $\alpha$ and $\beta$. Methods Enzymol. 1955;1: 149-58.

29. Lowry OH, Rosebrough NJ, Farr AL, Randall RJ. Protein measurement with the folin phenol reagent. J Biol Chem. 1951;193:265-75.
30. Laemmli UK. Cleavage of structural proteins during the assembly of the head of bacteriophage T4. Nature. 1970;277: 680-5.

http://dx.doi.org/10.1038/227680a0

31. Muniandy K, Kahar UM, Chong CS, Chai YY, Goh PH, Goh KM. Application of statistical experimental design for optimization of novel $\alpha$-amylase production by Anoxybacillus species. J Biol Sci. 2013;13:605-13. http://dx.doi.org/10.3923/jbs.2013.605.613

32. Ranjani V, Janeček $S$, Chai KP, Shahir $S$, Abdul Rahman RNZR, Chan KG, Goh KM. Protein engineering of selected residues from conserved sequence regions of a novel Anoxybacillus $\alpha$-amylase. Sci Rep. 2014;4:Article no: 5850. http://dx.doi.org/10.1038/srep05850

33. Kim DH, Morimoto N, Saburi W, Mukai A, Imoto K, Takehana T, et al. Purification and characterization of a liquefying $\alpha$-amylase from alkalophilic thermophilic Bacillus sp. AAH-31. Biosci Biotechnol Biochem. 2012;76:1378-83. http://dx.doi.org/10.10.1271/bbb.120164

34. Chakraborty K, Bhattacharyya BK, Sen SK. Purification and characterization of a thermostable $\alpha$-amylase from Bacillus stearothermophilus. Folia Microbiol. 2000;45:207-10.

35. Goyal N, Gupta JK, Soni SK. A novel raw starch digesting thermostable $\alpha$-amylase from Bacillus sp. I-3 and its use in the direct hydrolisis of raw potato starch. Enzyme Microb Technol. 2005;37:723-34.

http://dx.doi.org/10.1016/j.enzmictec.2005.04.017

36. Colak A, Col M, Çanakçi S, Beldüz AO, Omarov I. Investigation of extracellular highly thermostable starch hydrolyzing activity from a novel thermophilic bacterium Anoxybacillus gonensis A4. Asian J Chem. 2008;20:1577-87.

37. de Cordt S, Hendrickx M, Maesmans G, Tobback P. The influence of polyalcohols and carbohydrates on the thermostability of $\alpha$-amylase. Biotechnol Bioeng. 1994;43:107-14. http://dx.doi.org/10.1002/bit.260430202

38. Khajeh K, Shokri MM, Asghari SM, Moradian F, Ghasemi A, Sadeghi $\mathrm{M}$, et al. Acidic and proteolytic digestion of $\alpha$-amylases from Bacillus licheniformis and Bacillus amyloliquefaciens: stability and flexibility analysis. Enzyme Microb Technol. 2006;38:422-8.

http://dx.doi.org/10.1016/j.enzmictec.2005.06.021

39. Srivastava RAK. Purification and chemical characterization of thermostable amylases produced by Bacillus stearothermophilus. Enzyme Microb Technol. 1987;9:749-54. http://dx.doi.org/10.1016/0141-0229(87)90036-6

40. Rao JLUM, Satyanarayana T. Purification and characterization of a hyperthermostable and high maltogenic $\alpha$-amylase of an extreme thermophile Geobacillus thermoleovorans. Appl Biochem Biotechnol. 2007;142:179-93. http://dx.doi.org/10.1007/s12010-007-0017-4

41. Negi S, Banerjee R. Characterization of amylase and protease produced by Aspergillus awamori in a single bioreactor. Food Res Int. 2009;42:443-8. http://dx.doi.org/10.1016/j.foodres.2009.01.004

42. Tunga R, Banerjee R, Bhattacharya BC. Some studies on optimization of extraction process for protease production in SSF. Bioprocess Eng. 1999;20:485-9. http://dx.doi.org/10.1007/s004490050619

43. Ben Abdelmalek-Khedher I, Urdaci MC, Limam F, Schmitter JM, Marzouki MN, Bresollier P. Purification, characterization, and partial primary sequence of a major-maltotriose-producing alpha-amylase, ScAmy43, from Sclerotinia sclerotiorum. J Microbiol Biotechnol. 2008;18:1555-63.

44. Shafiei M, Ziaee AA, Amoozegar MA. Purification and biochemical characterization of a novel SDS and surfactant stable, raw starch digesting, and halophilic $\alpha$-amylase from a moderately halophilic bacterium, Nesterenkonia sp. strain F. 
Process Biochem. 2010;45:694-9.

http://dx.doi.org/10.1016/j.procbio.2010.01.003

45. Tatar S. Amylase enzyme production and investigation of possibilities in industrial usage from thermophile moderately halophilic Bacillus sp. [Master's Thesis]. Adana, Turkey: Çukurova University; 2007.

46. Das K, Doley R, Mukherjee AK. Purification and biochemical characterization of a thermostable, alkaliphilic, extracellular $\alpha$-amylase from Bacillus subtilis DM-03, a strain isolated from the traditional fermented food of India. Biotechnol Appl Biochem. 2004; 40:291-8.

http://dx.doi.org/10.1042/BA20040034
47. Ivanova VN, Dobreva EP, Emanuilova EI. Purification and characterization of a thermostable alpha-amylase from Bacillus licheniformis. J Biotechnol. 1993;28:277-89. http://dx.doi.org/10.1016/0168-1656(93)90176-N

48. Hsieh MS, Yin LJ, Jiang ST. Purification and characterization of the amylase from a small abalone Haliotis sieboldii. Fish Sci. 2008,74:425-32. http://dx.doi.org/10.1111/j.1444-2906.2008.01540.x

49. Nielsen JE, Borchert TV. Protein engineering of bacterial $\alpha$-amylases. BBA - Protein Struct M. 2000;1543:253-74. http://dx.doi.org/10.1016/S0167-4838(00)00240-5 